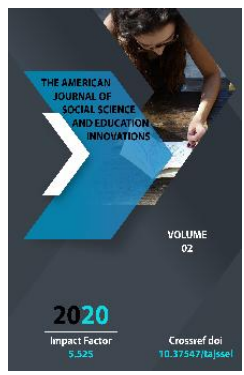

\title{
Legal Nature Of Tax Audits: In Uzbekistan And Foreign Countries
}

\author{
Normatov Bekzod \\ Senior lecturer, Administrative and financial Law Department, Tashkent State University of \\ Law, Tashkent, Uzbekistan
}

Journal Website:

http://usajournalshub.c

om/index,php/tajssei

Copyright: Original

content from this work

may be used under the

terms of the creative

commons attributes

4.0 licence.

\section{ABSTRACT}

In this article, the concept, essence, types and theory of tax audits are analyzed, as well as tax audits are associated with the activities of tax administration, tax discipline and tax authorities. The theoretical and legal basis of tax audits was analyzed through the tax system of national and foreign countries. Models for tax audits and the introduction of electronic technologies into the activities of tax authorities have been discussed.

\section{KEYWORDS}

Tax audit, type of tax audit, tax discipline, tax administration, tax authority, desk audit, office audit, on-site audit.

\section{INTRODUCTION}

Etymology of checking. In the dictionary of the Uzbek language there are two meanings of the word" check", the first is to look to know and determine the real case, and the second is to look for contro[1]. In Russian language check means - to make sure that something is correct, to examine for the purpose of supervision, control[2]. Also, check from the English language is characterized by the concept of audit. Its meaning goes back to Latin, "sense or act of hearing," from audire "to hear" -tus[3]. Check (examination, inspection, audit) in legal dictionaries means the one - time control of the bodies that control how laws and other legislative acts that regulate their activities are carried out by economic entities[4]. The tax audit, as the main form of tax control, examines the correct circulation of taxpayers' financial assets from the point of view of payment of taxes. Tax control is a type of financial control, and financial control in turn is a type of state control. 


\section{TAX COLLECTION THEORY}

So far, there have been various theories on tax collection. In particular, it is the French Sebastian de Voban (the theory of the "community agreement" of 1633-1707 years) and Charles Monteske (the theory of the "public agreement" of 1689-1755 years), which are manifestations of the atomic theory. Supporters of this theory have tried to understand that taxes are considered an agreement between citizens and the state and citizens are paying tax payments for the protection, security and other services of the state. From this, it is believed that no one will be able to refuse public services, nor will they be able to refuse the payment of taxes. In the end, it is noted that this transaction is the most profitable, and even the weakest state can better and preferably protect each citizen than it provides for self-security. In other words, taxes were considered the payment of Citizens for their peaceful existence. British economists Thomas Gobbs (1558-1679 years), Voltaire (1694-1778 years) and Onore Mirabo (1749-1791 years) were also considered supporters of this theory[5].

Besides that Adam Smith in The Wealth of Nations (1776) wrote: "Such things as defending the country and maintaining the institutions of good government are of general benefit to the public. Thus, it is reasonable that the population as a whole should contribute to the tax costs. It is also reasonable to demand certain other things of a tax system - for example, that the amounts of tax individuals pay should bear some relationship to their abilities to pay... Good taxes meet four major criteria. They are (1) proportionate to incomes or abilities to pay (2) certain rather than arbitrary (3) payable at times and in ways convenient to the taxpayers and (4) cheap to administer and collect [6]."
"In this world nothing can be said to be certain, except death and taxes" - these are the words of Benjamin Franklin, written in 1789 in a letter to the French scientist JeanBaptiste Leroy. Two hundred years later in 1989 an article called "The anatomy of tax evasion" was published. The article starts: "Three things are certain in life: death, taxes, and mankind's unrelenting effort to evade both" (Klepper and Nagin, 1989)[7]. Overall, taxes are the main attribute of co-existence of state, society and people by living peacefully in tax agreement.

\section{THE CONCEPT OF TAX AUDIT (INSPECTION)}

There are a number of definitions and concepts related to tax audit between legal literature and law scholars. Russian scientists. According to Z.P.Gasieva and V.A.Kaytmazov, is tax audit is the main and most effective form of tax control[8]. According to S.A.Shornikov, tax inspection is a form of tax control, consisting of a complex of measures aimed at eliminating violations and their causes in the field of taxation, which ensure the correct calculation and timely full payment of taxes and levies carried out by the tax authorities within their competence, regulated by the legislation, as well as the application of measures of responsibility[9]. G.S.Aytkhojina stated tax inspections are prosessual actions aimed at controlling the correct calculation of taxes and fees carried out by the tax authorities and their full payment in due time[10].G.G.Nesterov, N.A.Poponov and A.V.Terzidi stated that the conduct of tax inspections by the competent authority is understood as a narrow sense of tax control[11].A.A.Mironova notes that taxes are an object of conflict - binding monetary relations in their nature, while tax checks are considered an object of necessity by the state as a form of tax control[12]. 
According to N.N.Shestakova, tax inspections are one of the effective forms of tax control, tax inspections are divided into desk and onsite inspections[13].T.A.Silvestrova, Yu.A.Sokolova and D.G.Nazarov stated that the main form of control over the timely full payment of taxes by taxpayers by the tax authorities is tax inspections, carried out in desk and mobile methods[14].According to Y.A.Puzirova, tax audits are a set of prosessual actions on the control of the taxpayer and tax agent compliance with tax legislation by comparing the financial and economic activity of the tax authority with the financial and economic activity of the taxpayer by comparing its reporting data[15].

M.N.Sadchikov believes that the tax audit is the main form of tax control and expresses the complex of the prosessual actions of the competent authority, which is carried out by comparing the tax agent for the control of compliance with tax legislation, as well as the accounting data of tax and collection payers, their state of financial and non-financial activities[16].According to Y.Krokhina, tax inspection is the main form of tax control, a comparison of the existing financial statements of taxpayers' financial and economic activities on taxes and fees by the competent authorities[17].According to A.Demin, the study of the compliance of tax inspections with the law by the competent authorities of taxpayers and tax agents through documentary and legal checks on the calculation, retention and payment of taxes and $[18]$.

According to A.Tagaev, the tax inspection is the verification of the information contained in the tax reports submitted to the tax service bodies and other documents pertaining to taxpayers, financial statements, declarations, documents submitted by the relevant authorities, based on common interests, based on the legal rights granted to them by the employees of the tax authorities, carried out for the purpose of providing[19].Another lawyer scientist Y.Zikeev stated, the tax inspection is one of the main forms of tax control, it is carried out by the tax authorities, except for the bodies of the tax service, no one can carry out tax inspections[20].According to L.I.Kofler and Y.P.Kashirina, the tax inspection is a control movement of the tax authorities, aimed at the correct calculation and timely full payment of taxes and mandatory payments to the budget[21].

In the opinion of T.Y.Kurbatov, tax inspection is one of the most effective measures that are used by tax authorities in relation to dishonest taxpayers associated with the prosecution of persons who violate tax legislation[22].According to L.V.Spirina, tax inspection is a set of special methods of tax control, which are used by the competent authority to establish the reliability and legality of the procedure for payment of taxes and fees in the objects of taxation, as well as in accounting reports and other documents[23].According to V.A.Tymoshenko, tax inspections are a component of financial inspections, such as the process of state registration and accounting of a taxpayer, reports from taxpayers and receipts to the budget, the examination of objects of taxation with other financial and check activities of taxpayers[24].

According to M.A.Dudkin, tax inspection is the prosessual act of the tax authority on the correct calculation of taxes and fees, as well as on the control of their full and timely payment. This is done by comparing the economic circumstances obtained as a result of tax control and the tax returns submitted to the tax authorities[25].N. A.Kuprianova and N.N. Laychenkova believes that the tax inspection is a procedural action by the tax 
authorities on the correct calculation of taxes and fees, timely and complete payment, as well as control over compliance with tax legislation, divided into desk and on-site inspections, depending on the place of conducting tax inspections[26]. According to V.Lipsky, tax inspection as a form of tax control is an activity carried out within the limits of its competence with the aim of ensuring the correct calculation and payment of taxes and fees by tax and other supervisory bodies[27]. In our opinion, the tax inspection is the sum of measures taken by the tax authorities to control the compliance of taxpayers with the tax legislation related to the timely full payment of taxes and fees.

\section{UZBEK SCIENTISTS}

M.I.Alimardonov believes that in the inspections carried out by the tax authorities, it is desirable to establish a permanent monitoring on the fulfillment of the requirements of tax laws, decrees and decisions by the department coordinating the activities of the supervisory bodies[28].In the opinion of K.Sindarov and I.Jumanazarov, the concept of inspection is broader, and revision is one of its types. The definitions of the concepts "inspection" and "revision" given in the law could not fully reveal the essence of these words[29].

According to I.Ergashev, analyzing the requirements of the tax legislation of the Republic of Uzbekistan, it should be noted that tax inspection as the main form of tax control is manifested. Because it is precisely this form of tax control that allows taxpayers to timely and quickly determine the fulfillment of their obligations[30].According to F.Isayeva, tax control is carried out by the bodies of the state tax service taking into account taxpayers, tax objects and tax related entities, receipts falling into the budget and state-owned funds, as well as other forms provided for by the tax inspection and tax legislation[31].In our opinion, tax inspections are the sum of administrative, profilactic and informative measures taken by specially authorized employees of tax authorities aimed at ensuring timely and complete reduction of taxes and fees in the budget.

\section{FOREIGN SCIENTISTS}

Katharina Gangl, Eva Hofmann, Erich Kirchler stated that to overcome the social dilemma and to insure high tax compliance among citizens, tax authorities rely on two measures. Power measures such as audits and fines and trust related measures such as fair procedures. There is little doubt that audits and fines are necessary to levy taxes, however, they are not the only determinants to ensure contributions. Experiments on tax behavior in the laboratory have consistently supported the positive impact of audits and fines on compliance (Blackwell, 2007). Nonetheless, the effects are rather weak. Field studies and surveys have yielded effects that are lower than, and sometimes the opposite of the predicted effects (e. g., Andreoni, Erard, \& Feinstein, 1998). Additionally, Feld and Frey (2007) question whether audits and fines may destroy trust, as they crowd out the intrinsic motivation to cooperate among committed and cooperative citizens. Thus, besides "economic" determinants such as audits and fines, "psychological" determinants such as the motivation to comply, the attitudes of taxpayers towards the state, the government and taxation, transparency and understanding of tax laws, personal and social norms, and fairness perceptions were shown to impact tax compliance (Braithwaite, 2003; Kirchler, 2007; Torgler, 2003)[32]. 
Agumas Alamirew Mebratu stated that tax audit can play a major role in improving tax administration and overall taxpayer compliance by impacting on taxpayer behavior. Since the contribution of tax audit on improving tax payer's compliance is significant among other measures, revenue authorities of the country and other concerned parties should give more emphasis on the role of tax audit by fulfilling the required staff and qualifications to improve tax payer's compliance and thereby increasing countries revenue through tax. Tax compliance has a multi-faceted measure and theoretically, it can be defined by considering three distinct types of compliance such as payment compliance (timely payment of all obligations), filing compliance (the timely filing of any required return), and reporting compliance (the accurate reporting of income and of tax liability)[33].

Jean Bosco Harelimana stated tax audit actually has an effect to revenue collection as according to the $t$ - tests there is significance in the correlation between tax collected before the audit and after the audit. This clearly indicates that tax audit increases revenue collection. That in essence means that the more the tax audit conducted the more revenue is collected. Thus, it is right to say that tax audit is directly related to revenue collection. All the tax audits are important because they add something to revenue and thus should be encouraged as it assists the government in collecting appropriate tax revenue[34].

David John Hoey stated tax audit a review or examination of a firm's accounts to verify that their information has been reported correctly[35].Catherine C Rotich, Symon K Kiprop, Paul M Nzioki stated tax audit can be termed as a verification of a tax return by tax officers to check and confirm that the income reported and expenditure claimed from the same are correct. It involves examination of tax returns in relation to the taxpayer's records and books of accounts[36].

Zakir Akhand and Michael Hubbard stated tax agencies have used diverse techniques to increase compliance, depending on the type of taxpayer and the amount of revenues at stake. The techniques chosen are motivated by two apparently opposing strategies that have dominated the tax compliance debate: the coercive and the persuasive approaches. 2 The coercive tax compliance approach, also called the deterrence or stick-based approach, attempts to promote tax compliance through a mix of penalties and tax audits, whereas the persuasive approach, also called the collaborative, cooperative, or carrot-based approach, seeks to increase tax compliance by raising taxpayer morale through better taxpayer services, tax simplification, administrative procedures, mutual understanding, and education of taxpayers, among others[37].

Agung Darono and Danny Ardianto stated tax administration has the authority to determine the amount of tax payable regardless of the tax regimes followed: self-assessment, official assessment, or withholding. It will then need to determine the amount of tax in question. Audits are one of the most prevalent ways to obtain that amount. Tax audits are concerned with collecting and transforming evidence from multiple sources in order to conclude whether the audited taxpayer has complied with the law. If the taxpayer were found to be non-compliant, relevant penalties shall be given. In other words, tax audits hold a central role in the enforcement of tax laws[38].

Suhirman Madjid stated auditing are series of collectiong and data processing, information, evidence that done in objective and professional way depend on a checking standart to test tax reporting complieance 
and/ or other goal to imply criteria of the tax regulation[39].Mohd Rizal Palil stated taxes are compulsory but fines are avoidable. As with tax audits, penalties and fines also appear to play a significant role in the success of SAS (self-assessment system). In a SAS, taxpayers are also faced with a more difficult tax compliance task when compared to a direct assessment system. Since SAS is heavily reliant on the honesty of taxpayers and is also not subject to complete scrutiny or assessment by the tax authority, the execution of penalties is important compared to in a direct assessment systems. A possible explanation for this is that very few taxpayers will be likely to be involved with tax audits, and so penalties and fines take on a critical behaviour-influencing role in helping to improve tax compliance[40].

Charles Vellutini stated first, audits are used to detect and redress individual cases of noncompliance. This is the direct and most straightforward influence of audits on compliance and revenue collection. Second, audits promote voluntary compliance by increasing the probability of detection and penalties for noncompliant taxpayers. This impact critically depends on a properly designed audit selection strategy focusing on high-risk taxpayers. Similarly, audits provide a good opportunity for the tax administration to educate taxpayers on their legal obligations or bookkeeping requirements, thereby improving future compliance. Third, audits are unique opportunities for tax administrations to gather information on both the health of the tax system (by measuring the share of noncompliant taxpayers and the amount of unpaid taxes, for example) and the evasion techniques used by taxpayers[41].

Sacit Hadi Akdede stated in some countries, this collusion can really happen on purpose because the tax collector can "collect" small bribes from small businesses and the tax inspector can deliberately reduce the probability by keeping their number sufficiently low. They do it so because after working in a high level public inspection institution for a number of years, they transfer to the "big" businesses with more profitable positions. By keeping their number sufficiently low, they control the supply of their knowledge deliberately and gain a reputation in the sense they are not corruptible. After changing their position from the public office to private companies, they go with their "insider information" and cause the higher level tax evasion or lobbying which might increase the inefficiencies[42].

Barış Yıldız stated early period tax application theories presented that higher tax auditing levels led to higher tax compliance levels. Moreover, empirical researches done in the recent years revealed complicated evidences in respect to this relationship and emphasized that in order to increase tax compliance determinants affecting these shall be specified and taken into consideration. Tax audits, where these determinants are not taken into consideration, may decrease tax payers' tax compliance and may bring out Bomb Crater Effect. Using facilitating and improving techniques for site and random audits, designing different audits in order to determine recurring violations and offenders, adjusting audits in accordance with the level of tax evasion, regulating audit criteria by taking profession, age and sex groups into consideration and updating them in accordance with current conditions, and examining the relationship between tax payers with low compliance levels and other tax payers may contribute to the compliance of tax payers and may prevent the arising of Bomb Crater Effect[43].

Frans Vanistendael stated that the principle of fair play or public trust means that the taxation authority must not be allowed an 
unfair advantage in its dealings with taxpayers. Application of this principle suggests that (1) the authority must notify a taxpayer of any action the authority may take relating to that taxpayer, (2) during litigation, a taxpayer must be afforded all the rights of process allowed the authority, and (3) the authority must be bound by its interpretation of the law as applied to a taxpayer's particular situation. In most countries, these rules of fair play are part of the general administrative law. However, exceptions to these rules can be made when fair play does not suffer as a result. For example, an authority may take action without notice if it reasonably suspects that the taxpayer would destroy evidence or flee the jurisdiction[44].

Joel Slemrod stated the most careful and comprehensive estimates of the extent and nature of tax noncompliance anywhere in the world have been made for the federal taxes that the U.S. Internal Revenue Service (IRS) oversees. The IRS has, beginning in 1979, periodically estimated what it calls the "tax gap," meaning how much tax should be paid, but is not paid voluntarily in a timely way (U.S. Department of the Treasury, Internal Revenue Service, 2005b, 2005d, 2005e, 2006). These studies provide separate estimates of the failure to pay the proper amount of tax due to nonfiling; underreporting of tax due on tax returns; and nonpayment or late payment of taxes owed. The IRS comes up with its estimates by combining information from a program of random intensive audits, originally known as the Taxpayer Compliance Measurement Program (TCMP), with information obtained from ongoing enforcement activities and special studies about particular sources of income - for instance, the tips and cash earnings of informal suppliers like nannies and housepainters - that can be difficult to uncover even in an intensive audit[45].
Antonio Pedone stated the sharp rise in income tax revenue that occurred immediately after the introduction of Irpef (personal income tax in progressive) was mainly attributable to three factors that were not accurately anticipated and were not readily foreseeable in terms of their eventual magnitude. The second factor, which is particularly significant for the purposes of this discussion, is the introduction of new methods of tax assessment and, above all, of tax collection, including the extension of withholdings at source, forms of selfassessment and the payment of tax instalments on account. Some of these innovations were very effective in securing a high and regular flow of tax revenue, but because of their varied application to different types of income, they actually accentuated the differentiation of tax treatments of such income, due also to the methods used to check tax returns, the conducting of tax audits and the imposition of penalties by tax authorities[46].

Sandro Casal stated in the light of these considerations, and summarizing the role of audit rates, from a behavioural economics point of view, it can be argued that tax behaviour is driven more by a subjective expectation of a personal audit, rather than the actual and real value of audit probabilities. Studying the impact of audit probabilities on tax compliance makes sense only if consequences for a detected evasion (fines or criminal conviction) are also considered: it is clear that, if one of the two variables is set to zero, neither the most severe penalty nor the most accurate audit scheme can guarantee full compliance. Most of the studies presented above do indeed consider both variables: results on the deterrent role of fines are not always unanimous[47].

Henrik J. Kleven, Martin B. Knudsen, Claus T. Kreiner, Søren Pedersen, and Emmanuel Saez 
stated that we may think of the detection probability as a product of two probabilities: the probability of audit and the probability of detection conditional on audit. Audits may affect the perceived detection probability through both channels. One would expect the effect on the perceived audit probability to be positive. The effect on the perceived probability of detection conditional on audit is ambiguous, because the taxpayer may learn that the tax administration is either more or less effective at uncovering evasion than expected. However, because of the way the audit procedure works (in the experiment and outside the experiment), it is most likely that the audits have a positive effect on the perceived probability of detection conditional on being audited. This is because audited taxpayers are contacted only if tax inspectors upon examining the return believe that hidden income or unjustified deductions can potentially be uncovered. Hence, taxpayers are typically only aware of being audited in cases where tax inspectors are successful. Hence, the probability of detection conditional on audit (as well as the audit probability) is likely to increase as a result of experiencing an audit, in which case the standard economic model predicts an increase in reported income. In particular, we would expect to see increases in self-reported reported income, but not necessarily in thirdreported income where the probability of detection is already close to one[48]. Izlawanie Muhammad stated from the tax authority's perspective, tax audit is an essential tool for ensuring tax compliance. It typically requires tax authorities to examine taxpayers' records and tax affairs to determine whether taxpayers' correct liability is reflected in returns and assessments[49]. In my opinion, theories of taxation and tax inspections depend on the economic and social situations of the state whether it is developing or developed which means it takes long time to reform and regulate tax compliance relations as targeted.

\section{TAX INSPECTION IN UZBEKISTAN}

Tax inspection in the Republic of Uzbekistan is the main form of tax control. The legal basis of tax inspections is the tax code of the new edition of December 30, 2019[50]. According to this code, it is established that tax inspections are carried out for the purpose of supervision over compliance with tax legislation by taxpayers, payers of fees and tax agents. Tax inspection is carried out by the tax authority, that is, the tax administration and its territorial units. The tax branch is a separate independent body from the Ministry of Finance. The activities of the tax administration are regulated on the basis of the regulations approved by the Cabinet of Ministers of the Republic of Uzbekistan[51].

According to the tax code, tax authorities conduct the following types of tax inspections: 1) desk tax inspection; 2) mobile inspection; 3) on-site tax audit. These inspections are regulated by separate regulations approved by the state tax administration. In particular, desk tax audits are regulated by the "regulations on the conduct of a desk tax audit", the "regulation on the conduct of a mobile tax audit", the "regulation on the conduct of a on-site audit".Desk tax inspection according to the "Desk tax inspection regulation", approved by the decree of the State Tax Committee of the Republic of Uzbekistan № 2020-14 of April 30, 2020 , is an inspection conducted by the tax authority by examining and analyzing the tax reports submitted by the taxpayer and (or) other information available in the tax authority on the activities of the taxpayer. Also, according to this regulation, a desk tax inspection is carried out in the following cases: 
when there is a high or moderate risk of committing a tax offense due to the level of risk of committing a tax offense, as a result of the software product "Risk Analysis"; when appeals to the Tax Authority of individuals and legal entities about a violation; when an error in the tax report and (or) discrepancies in the tax report are detected[52]. According to the regulations of the State Tax Committee of the Republic of Uzbekistan "on the procedure for carrying out the procedure of the mobile tax inspection, it is an examination of the performance of certain obligations of taxpayers in the field of calculation and payment of taxes and fees, as well as other obligations established by the tax legislation.

Also, according to this regulation, within the framework of the on-site tax inspection, the tax authorities carry out the following: identification of objects of taxation; conducting chronometric observations; verification of the application of control-cash technique and settlement terminals; monitoring of compliance of taxpayer employees with the report and the actual number; verification of compliance with tax legislation at the stops-parks; to demand from the taxpayer the transfer of fixed assets, commodity-material assets, funds and settlements by the taxpayer (tax agents). In addition, the on-site tax inspection is carried out on the following grounds: in the presence of data on tax violations in the activities of taxpayers (tax agents), which are determined by the result of the software product "riskanalysis", not belonging to the category of high risks; in the case of appeals from individuals and legal entities, as well as from judicial and law; in the case of the publication of information on tax violations in the mass media; when there is a need to study the discrepancies and errors identified in the process of the desk tax inspection outside the location of the tax authority[53].
According to the regulation "on conducting on-site tax audit"approved by the decree of the State tax Committee of the Republic of Uzbekistan № 2020-17 of May 18, 2020, the tax audit is a way of studying and comparing the accounting, finance, statistics, banking and other documents of the taxpayer with a view to calculating and verifying the correctness of payment of taxes and fees. According to this regulation, the tax audit is carried out in the following taxpayers: in taxpayers who belong to the category of high-level risk (tax risk) identified by the tax authority through the automated information system of risk analysis (software product "risk analysis"); as a result of the kameral tax audit, the Tax Authority did not provide a tax report in response to the request (including, after the identified application), which did not provide a basis for the identified discrepancies, or which found that the regulations provided were insufficient, in taxpayers belonging to the category of high risk (tax risk); in taxpayers subject to voluntary liquidation; in taxpayers in the case of the tax payers, where the criminal case is initiated; during the tax audit conducted previously, taxpayers who have identified new cases that are not known to the tax authority[54]. In general, the Institute of tax inspections in Uzbekistan is improving. In particular, a special risk-analytical system of the tax inspection process and the platform for electronic registration of inspections are being introduced.

\section{TAX AUDITS IN THE US}

The main normative legal acts on taxes and fees at present are: 1) the internal revenue Code of the United States of 1986; 2) Legislation on the state budget for the coming year; 3) the Law on stimulating economic development and establishing tax incentives In addition, in the United States, there are by- 
laws that are an important source of tax law, among them are the following types: 1) Rules (instructions) of the US Treasury: a) regulatory instructions on taxes and fees; b) methodological instructions. 2 ) rules (Revenue Rules) explaining the procedure for applying tax laws in relation to specific tax relations, issued by the tax service. However, the courts do not recognize any regulatory quality for them, and the us internal revenue service has the right to waive their provisions. 3) Separate letters of explanation. Any taxpayer has the right to apply to the us Department of the Treasury, as the main body in the apparatus of economic regulation at the Federal level, with the competence to address issues related to taxation and tax policy. The internal Revenue Service (IRS), which is controlled by the Ministry of Finance, has control and Supervisory powers in the tax sphere. This is the main tax Department of the United States. The internal revenue service, in addition to the Central office in Washington, includes regional offices that serve several States and local tax offices. The position of the head of this service is called: "Commissioner of internal revenue". The internal Revenue Service (IRS) is the largest structural division of the us Treasury Department[55].

As a US federal state, the tax code (Internal Revenue Code[56], Taxpayer Bill of Rights[57]) defines the general provisions of tax inspections. According to him, each resident and non-resident must submit tax returns on their income to the tax authorities (Internal Revenue Service, IRS). The tax authorities will check these declarations. An IRS audit is a review/examination of an organization's or individual's accounts and financial information to ensure information is reported correctly according to the tax laws and to verify the reported amount of tax is correct.
There are three types of audits the IRS may perform: correspondence, field, and office.

- A correspondence audit means that the IRS needs additional documentation from you, and you will be asked to mail it in. This is the most common type of audit, and you will not have to meet with an IRS agent.

- $\quad$ Field audits are generally done on businesses. In a field audit, an IRS agent will come to your business or home to look at your records.

- $\quad$ An office audit is just like it sounds. You will have to go to an IRS office to meet with an agent.

A correspondence audit is relatively limited in scope. An agent typically conducts the audit using letters and phone calls to work with the officers or a representative of the organization. A correspondence audit can expand and become an in-person (field) audit, particularly if the issues grow more complex or the organization does not respond.

The IRS manages audits either by mail or through an in-person interview to review your records. The interview may be at an IRS office (office audit) or at the taxpayer's home, place of business, or accountant's office (field audit). Remember, you will be contacted initially by mail. The IRS will provide all contact information and instructions in the letter you will receive[58]. Besides that IRS uses special programs to select taxpayers to make audit. Taxpayer Compliance Measurement Program (TCMP) for about 30 years, TCMP has been IRS' primary program for gathering comprehensive and reliable taxpayer compliance data. It is IRS' only program to measure noncompliance on a random basis, allowing IRS to make statistically reliable estimates of compliance nationwide. IRS uses the data for measuring compliance levels, estimating the tax gap, identifying compliance 
issues, developing formulas for objectively selecting returns for audit, and allocating audit resources. Congress and federal and state agencies have used TCMP data for policy analysis, revenue estimating, and research[59].In addition, within the framework of the federal Territory subjects, the Federal state determines in its legislation the exact procedure and grounds for tax inspections, in particular in the state code and tax legislation (for example, the Indiana Code[60]). As a general rule, individuals and legal entities in the US submit a tax declaration. The tax authority studies these declarations, accordingly appoints types of tax inspections.

Total Amount of IRS Audits on Individual Tax Returns

\begin{tabular}{|c|c|c|c|c|}
\hline & FY 2016 & FY 2017 & FY 2018 & FY 2019 \\
\hline $\begin{array}{c}\text { Total Returns Filed Prior } \\
\text { CY }\end{array}$ & $147,964,324$ & $149,919,416$ & $150,043,227$ & $152,624,939$ \\
\hline Total Audits Conducted & $1,034,955$ & 933,785 & 892,817 & 680,543 \\
\hline Percentage Audited & $0.7 \%$ & $0.62 \%$ & $0.59 \%$ & $0.4 \%$ \\
\hline
\end{tabular}

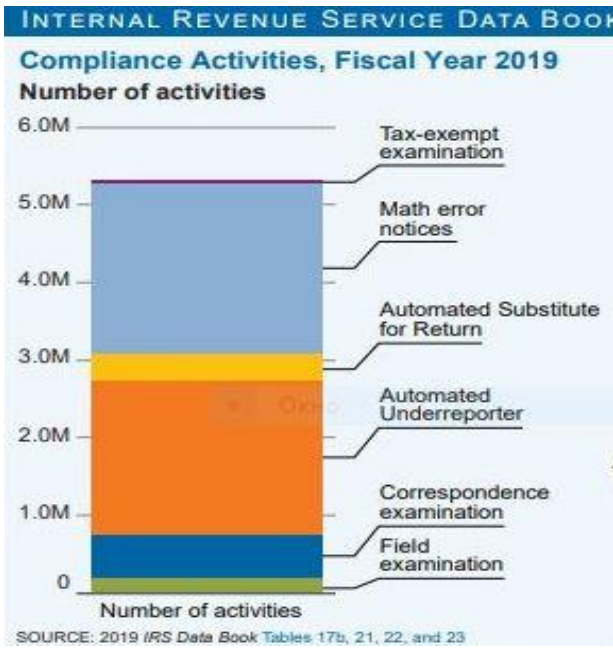

While the IRS accepts most returns as filed, some are selected for examination using various methods, including random sampling and computerized screening. Most IRS examinations are conducted through the mail (correspondence) or face-toface (field). The IRS gathers independent information about income received and taxes withheld from information returns, such as Forms $\mathrm{W}-2$ and 1099 filed by employers and other third parties. The IRS uses this information to verify
Recommended additional tax and assessments

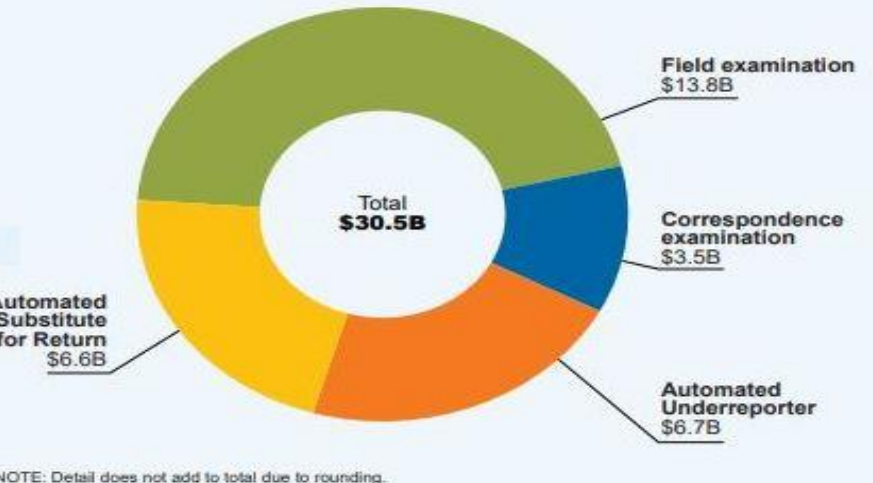

income and tax self-reported on returns filed by taxpayers. With its Automated Underreporter Program, the IRS matches these information returns to tax returns and contacts taxpayers to resolve discrepancies. In the Automated Substitute for Return Program, the IRS uses information returns from third parties to identify nonfilers; construct tax returns for certain nonfilers based on that third-party information; and assess tax, interest, and penalties based on the substitute returns. To further verify the 
accuracy of reported information, the IRS also checks for mathematical and clerical errors before refunds are paid. IRS's Criminal Investigation function conducts investigations of alleged criminal violations of the tax code and related financial statutes, which may in turn lead to prosecution, fines, and imprisonment.

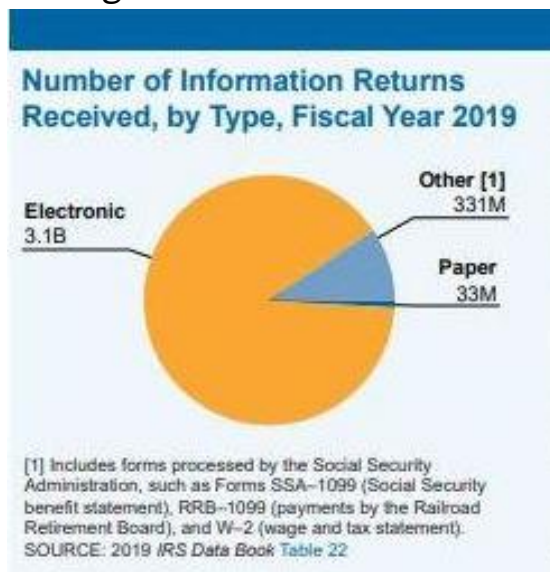

SOURCE: 2019 IRS Dats Book Table 22
Number of Returns Examined, by Examination Type, Fiscal Years 2010-2019

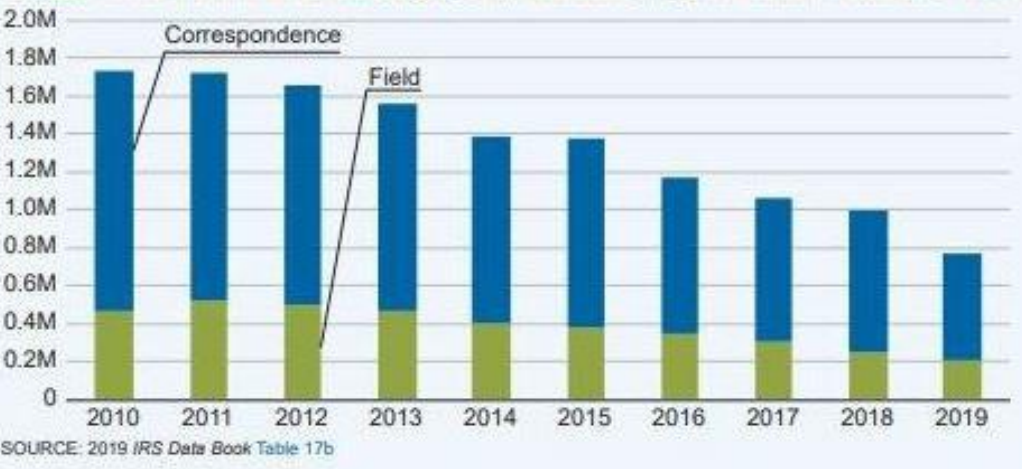

The IRS received more than 3.5 billion thirdparty information returns; 89.6 percent were filed electronically (Table 22). In Fiscal Year (FY) 2019, the IRS audited 771,095 tax returns, resulting in nearly $\$ 17.3$ billion in recommended additional tax (Table 17b). The majority of FY 2019 audits, 73.8 percent, were conducted via correspondence. The remaining 26.2 percent were conducted in the field (Table 17b)[61].

According to survey (2019 Comprehensive Taxpayer Attitude Survey (CTAS) Personal integrity is 'a great deal' or 'somewhat' of an influence to report and pay taxes honestly for $93 \%$ of taxpayers, followed by third party reporting (66\%) and fear of an audit (62\%). For millennials, fear of an audit and belief that friends, associates, and neighbors are reporting and paying honestly is more of an influence than for older taxpayers. Taxpayers agree that the more information and guidance the IRS provides, the more likely people are to correctly file their tax returns ( $89 \%$ agree). The most important IRS services for taxpayers are the IRS website for information (92\%), the toll- free number (89\%) and office locations (85\%) where IRS representatives can answer questions[62].In general, verification of the activities of taxpayers on account of the multiplicity of the number of taxpayers as a US federal state is carried out on the basis of a special program of mutual exchange of information online and on-site verification of them.

\section{TAX AUDITS IN CANADA}

On April 29, 1999, Parliament passed the Canada Customs and Revenue Agency Act, which established the Canada Customs and Revenue Agency (now the Canada Revenue Agency). The change in status from department to agency, which took place on November 1, 1999, has helped build a modern organization that is committed to leadership, innovation, and client service[63]. The legal basis of Canada Revenue Agency is Canada Revenue Agency Act[64].Besides that there is another important act which named The Income Tax Act requires taxpayers to keep such records and books of account as are required to determine the taxes payable and 
authorizes the Department to audit these for any purpose related to the enforcement or administration of the Act. To this end, the Act further authorizes the Department to request and receive from any person information, records, documents etc, within a reasonable, stipulated time. Under the Act, the Department may re-assess tax returns: (a) at any time in cases of fraud or misrepresentation, or where a waiver, specifying matters on which a reassessment may be issued, has been filed; or (b) at any time up to 4 years after the date of mailing the original assessment, in all other cases. The Department's audit program is directed mainly at those individuals deriving income from businesses and professions, as well as corporations and trusts[65].

There are two types of tax audits: remote audits, conducted in tax revenue offices; and on-site audits, conducted at a place of business. Every auditor is required to follow procedure when conducting an audit at a place of business. There are a number of steps in the process. Auditors are authorized by the Minister to exercise the audit and examination powers and duties provided for by the Revenue Administration Act[66]. Auditors must introduce themselves and, upon request, produce a document signed by the Minister attesting their authority.

No more than $2 \%$ of taxpayers can be checked annually. Therefore, the control activities of tax authorities are aimed at checking those of them who have a high risk of non-payment of taxes. The selection is performed by a computer through centralized processing of data that directly or indirectly characterize the financial condition of a particular payer, based on their comparison with average indicators. About 150 different parameters are taken into account for individuals, and 30 for corporations. For example, the fact that an individual taxpayer belongs to a risk group may be evidenced by a discrepancy between the income of this individual and the income of people living next to it. The more parameters of a taxpayer do not match, the more likely it is that this taxpayer did not fulfill the tax obligation properly. For these reasons, all taxpayers are divided into four levels of risk: from low to high. Data on taxpayers with a high degree of risk transferred to the territorial units to carry out inspections[67]. The CRA chooses a file for an audit based on a risk assessment. The assessment looks at a number of factors, such as the likelihood or frequency of errors in tax returns or whether there are indications of non-compliance with tax obligations. The CRA also looks at the information it has on file for the taxpayer and may compare that information to similar files or consider information from other audits or investigations[68].In Canada, taxpayers will be provided with a declaration of their income on the basis of self-assessment to the Canada Compliance Agency. The tax authorities have audited the declaration (Remote). In addition, on-site audit is carried out through a Special (risk-assessment systems) Program.

\section{TAX AUDITS IN FRANCE}

The relevant legislation is tax law, which is codified in the French Tax Code (FTC), which sets out the statutory rules applicable to the determination and filing of taxes, and the French Tax Procedure Code (FTPC), which sets out the rules governing tax-recovery procedures and tax controversies. Tax law is enacted by parliament (mainly through yearly finance acts) and must comply with: the French Constitution; international treaties duly ratified or approved by parliament and in force; the treaty on the functioning of the EU; the European Convention on Human Rights; and European directives issued by the EU[69]. 
The tax authorities (Direction Générale des Finances Publiques - DGFIP) are responsible for assessing and collecting taxes. The taxpayer has to file tax returns and the tax authorities will review them and assess afterwards. The tax year is the calendar year. Income taxes are not withheld, even in the case of employment income (although this will change with effect from 2019). There is only one exception from that rule, in the case of individuals with limited tax liability (nonresidents). Advance payments are required by law towards personal as well as corporate income tax. The tax authorities are allowed to carry out tax field audits. The statutory limitation for a tax audit is three years. The audits are carried out on corporate persons as well as individuals[70].

Tax audits in France take two fundamental forms: desk audits and field tax audits, both using different methods and following different procedures. The two main types of audits: The desk audits are carried out on the basis of taxpayers' returns and documents that the administration may get from third parties. They aim to address the absence of return, including sending reminders to defaulters, and to correct specific errors and irregularities that affect filed returns. Field tax audits, accounting audits for business and personal tax situation investigations for individuals, shall be notified to the taxpayers and follow strictly codified procedures[71].

The French tax authorities are responsible for verifying that taxpayers' obligations are correctly complied with and, if necessary, for making adjustments by issuing tax assessments. Once an assessment is notified by the tax inspector and if the taxpayer disagrees with such an assessment, the taxpayer has 30 days to answer (with a possible 30 days extension upon request) and to provide comments to the French tax authorities. Following an exchange of written correspondences between the tax inspector and the taxpayer (including hierarchical recourse), either party may submit any disagreement on a factual issue to the departmental or national tax commission. The decision of this commission is neither binding on the taxpayer nor on the French tax authorities. In cases where the disagreement between the French tax authorities and the taxpayer still remains, the taxpayer can file a claim with the French civil courts or with the French administrative courts, depending on the type of tax that has been subject to assessment by the tax inspector[72].

The French Tax Administration (FTA) is a generic name for all government agencies whose role is to establish the basis for direct and indirect taxes, allowing, afterwards, the Public Accountant to collect them. The FTA depends on the Ministry of the Economy and Finance. It is composed of the General Directorate of Public Finance (DGFiP) and the General Directorate of Customs and Indirect Taxes (DGDDI).According to the FTA's enforcement survey with respect to 2018, reassessed taxes and associated penalties were estimated at $€ 16.1$ billion. Tax audits resulted in the collection of $€ 8.7$ billion (compared with $€ 9.4$ billion in 2017). Approximately 2.8 million contentious claims were filed in 2018 and an equivalent number of claims were dealt with in 2017. The number of court proceedings filed in 2018 (about 22,000 ) was lower than the number of court proceedings filed in 2017 (about 23,000). Approximately 800 criminal claims for tax fraud were filed by the FTA in 2018[73].In general, in France, taxpayers file a declaration on taxes. The tax declaration is checked by the tax authority. In addition, the activities of some Oli payers through Random selection Program are subject to tax inspection.

TAX AUDITS IN GERMANY 
The Federal Central Tax Office (Bundeszentralamt für Steuern), as the higher federal authority in the portfolio of the Federal Ministry of Finance, performs numerous tasks with a national and international dimension which are assigned to it by the Financial Administration Act (FVG)[74]. The law provides no specific regulation as to when audits must be carried out or how often. The relevant tax office generally has discretion whether and when to audit a particular company within its jurisdiction. There are, however, tax audit administrative guidelines, Betriebsprifungsordnung 2000 (BpO 2000), which detail the proceedings of a tax audit and give some information about audit frequency. For example, the BpO 2000 states that "large" companies (trading companies with turnover of greater than Euro 5.95 million or taxable profit of Euro 232,500) and producing companies with turnover of greater than Euro 3.4 million or taxable profit of Euro 207,500 generally will be audited continuously. Mediumsized or small companies normally will not be audited every year. Furthermore, large multinational companies generally will be subject to more frequent audit reviews, particularly if the German subsidiary has experienced losses for a number of years.

Generally, for the corporate, the income, and the trade tax purposes, the statute of limitations to instigate an audit is four years after the year in which the tax return was due. However, if the tax authorities issue a tax assessment subject to the right to review, the period of limitation will be suspended from the time an audit is commenced until the date of effectiveness of an amended tax assessment notice issued on the basis of the audit. In the case of a revenue misstatement or tax evasion, the statute of limitations is ten years.As a rule, the local fiscal authorities of the individual federal states perform tax audits. In addition, the Federal Finance Office (Bundesamtfiir Finanzen) is authorized to participate in tax audits conducted by the regional tax authorities. The finance office may also carry out tax audits itself by agreement with the regional tax office, which otherwise has jurisdiction over a certain case. This will be the case particularly with audits involving non- German companies as well as audits that extend beyond the territory of the respective state[75].

Tax audits are carried out in accordance with the drawn up control audit plans, which are approved by the head of the tax authority annually and quarterly. Higher tax authorities do not have the right to participate in the development of these plans, but they have the right to independently conduct inspections of individual payers of taxes and fees, which have an extensive structure of production. In Germany the term for a major company in the notice on carrying out of tax checks is four weeks before the start of this tax audit, the date of receipt of the notification medium enterprise co-provides three weeks, and the period of receipt of the notification of a small business is one week. The tax payer can postpone the start date of the tax audit if there is a valid reason. The duration of tax audits in Germany is 25-30 days for large enterprises, 15 days for medium-sized enterprises, and 6-8 days for small enterprises[76].

With some exceptions, every business is obliged to keep accounting records and prepare financial statements (statements of financial position (balance sheets) and income statements) for a period not exceeding 12 months. Micro-entities are defined as companies that - on two consecutive balancesheet dates - exceed no more than one of the following three criteria: balance-sheet total350000 euro, turnover-700 o00 euro, average 
number of employees-10.Small companies are defined as companies that - on two consecutive balance-sheet dates - exceed no more than one of the following three criteria: balance-sheet total-6 000000 euro, turnover12000000 euro, average number of employees-50. Medium-sized companies are defined as companies that - on two consecutive balance-sheet dates - exceed no more than one of the following three criteria: balance-sheet total-20 000000 euro, turnover-40 000000 euro, average number of employees-250. Large companies are defined as companies that - on two consecutive balance-sheet dates - exceed more than one of the following three criteria: balance-sheet total- more than 20000000 euro, turnovermore than 40000000 euro, average number of employees- more than 250[77].

Table 4.1 Audit Frequency in Relation to Business Size in Germany

\begin{tabular}{lcccc}
\hline Segment & $\begin{array}{c}\text { Number of } \\
\text { businesses }\end{array}$ & $\begin{array}{c}\text { Number of busi- } \\
\text { nesses audited }\end{array}$ & \% of oudits & $\begin{array}{c}\text { Frequency of } \\
\text { audits (years) }\end{array}$ \\
\hline Large & 170,060 & 39,885 & 23.5 & 4.26 \\
Medium & 758,051 & 56,999 & 7.5 & 13,3 \\
Small & $1,141,146$ & 44,114 & 3.9 & 25.87 \\
Micro & $6,321,465$ & 69,638 & 1.1 & 90.78 \\
\hline
\end{tabular}

Source: Gemany, Ministry of Finance 2008 .

In general, the tax administration in Germany and the risk-based audit were adopted by the standards of the European Union. Depending on the category of taxpayers (business entities), tax inspections are carried out.

\section{TAX AUDITS IN SOUTH KOREA}

The Tax Bureau of the Ministry of Finance and Economy is responsible for drafting tax laws, negotiating international tax treaties and for the preparation of the tax revenue section of the national budget. The National Tax Service, an agency of the Ministry of Finance and Economy, oversees the assessment and collection of internal taxes[78]. The Korean Constitution establishes that 'types and rates of taxes shall be determined by law', thus all taxes must be imposed according to statutes passed by the National Assembly. Fundamental laws containing the basic rules of Korean taxes are as follows: the National
Tax Basic Law (NTBL), which prescribes the general tax requirements, including a taxpayer's rights and obligations; the National Tax Collection Law (NTCL), which stipulates the requirements for the collection of taxes; the Corporate Income Tax Law (CITL); the Personal Income Tax Law (PITL); the ValueAdded Tax Law (VATL); and the Local Tax Law (LTL) for rules prescribing tax liabilities for specific taxable items imposed by local governments. Relevant presidential decrees and ministerial decrees for each law above also function as sources of law[79].

In general, regular tax audit cycle for company with gross revenue equal or more than KRW 100 billion is 5 years. In practice, companies in Mutual investment restriction business groups or with assets of KRW 200 billion or more and its gross revenue exceeding KRW 50 billion are rotationally chosen by the tax authority to conduct tax audits in 5-year terms. However, targeted or special audit investigations can be performed at any time[80].Companies whose sales revenue exceeds KRW 150 billion are 
generally subject to a five-year periodic tax audit. Other audit target companies are selected by certain standards, which are announced by the National Tax Service (NTS). An official notification of an intended tax audit must be made 15 days prior to the audit[81]. According to the latest national tax statistics for 2018 which were released in 2019, only $0.075 \%$ of around 6.4 million sole proprietors were subject to tax audits by the National Tax Service (NTS) during 2018. On the other hand, the companies subject to NTS audits represented $0.623 \%$ of the total number (i.e., around 770 thousand) of the companies which filed their corporate income tax returns during the year. This figure was approximately eight times as much as the percentage share of the sole proprietors audited during 2018. In terms of the ratio of the companies audited in 2018, there was a significant difference depending on the sales revenue amount of the companies. The companies audited during 2018 break down to: $22.3 \%$ or 169 out of the total of 755 corporations having annual sales revenue exceeding $\mathrm{KRW} 500$ billion; $21.8 \%$ or 635 out of 2,913 corporations having annual sales revenue ranging from $\mathrm{KRW}_{500}$ billion to KRW100 billion. In other words, one in five large corporations were audited by the NTS during the year. This result is almost aligned with the direction of the five-year periodic audit policy of the NTS. The ratio of audited companies declined in case of companies other than large companies. The ratio declined to $10 \%$ for the companies whose annual sales revenue ranges from KRW100 billion to $\mathrm{KRW}_{30}$ billion and $1 \%$ for those having the annual sales revenue of KRW 5 billion or less. Particularly, for the small companies having the annual sales revenue of KRW500 million or less, the ratio of those audited fell to $0.05 \%$, lower than the average ratio for sole proprietors audited. The audits by the NTS Seoul Regional Office accounted for the highest portion of $0.83 \%$ of the taxpayers audited, followed by the audits by the Jungbu Regional Tax Office which recorded $0.62 \%$ of those audited. Meanwhile, on January 29, 2020, the NTS announced its national tax administration policy for 2020 during the meeting of commissioners of district tax offices. The policy addresses the support for taxpayers in undertaking tax reporting and compliances by providing data and analysis designed to suit needs and characteristics of taxpayers based on big data analysis. In addition, it also addresses the NTS plan to expand the effective pre-filing guidance through the analysis of non-compliance cases identified during the course of tax audits. By providing information and guidance on selected tax compliance items to relevant taxpayers, the pre-filing guidance seeks to help them voluntarily meet the tax return filing requirements more easily and promptly[82].

Basic Code of Tax Audit Tax audit should be faithfully executed according to the following: 1. Protect taxpayers' rights and interests 2. Due diligence 3. Substance Over Form doctrine 4. Documentary of taxation 5. Proportion of Investigation 6. Prohibition of abuse of investigation authority 7. Prohibition of disturbance of property right 8 . Prohibition of retroactive taxation 9. Strict adherence to discretionary limitation of Auditor. An audit should be performed during the taxpayer's regular working hours[83]. In general, in Korea, the system of Electronic Declaration and electronic verification is established on the basis of tax checks e-tax administration printsip. Tax checks are selected through special programs.

\section{TAX AUDIT IN JAPAN}

The National Tax Agency, an external organ of the Ministry of Finance, is in charge of the 
assessment and collection of internal taxes. It supervises 12 Regional Taxation Bureaus throughout Japan, under which 524 local tax offices are set up to execute tax administration[84]. The NTA was organized in 1949 as an external organization of the Ministry of Finance. The NTA supervises 12 Regional Taxation Bureaus (including the Okinawa Regional Taxation Office, and the same applies hereinafter) and 524 Tax Offices throughout Japan. There is also the National Tax College which trains tax officials, while the National Tax Tribunal serves as a special body engaged in examining requests for review from taxpayers[85].

Articles 30 and 84 of the Japanese Constitution require that all taxes be imposed by acts of the Diet. The legislation that is relevant to the procedural aspects of taxes in Japan includes:

- $\quad$ The National Tax General Rule Act (Act No. 66 of 1962), which deals mainly with matters generally related to national taxes, such as time limits for the tax authority to issue tax assessments, penalties for failure to file tax returns and rules on tax audits;

- The National Tax Collection Act (Act No. 147 of 1959), which stipulates the procedures for collection of national taxes; and

- The National Tax Violation Control Act (Act No. 67 of 1900), which sets out the criminal procedures related to evasion of national taxes.

Some pieces of legislation that mainly deal with substantive aspects of national taxes also provide procedural rules related to national taxes, such as the Income Tax Act (Act No. 33 of 1965), the Corporation Tax Act (Act No. 34 of 1965), the Inheritance Tax Act (Act No. 73 of 1950), the Consumption Tax Act (Act No. 108 of 1988) and the Act on Special Measures Concerning Taxation (Act No. 26 of 1957)[86].
For the tax authorities to conduct a correction or determination according to law, it is indispensable to have full access to materials relating to the facts of the case. Tax laws empower the tax authorities (i,e. tax officials) to make inquiries of the taxpayer and examine material evidence in order to obtain the necessary data. Such inquiries and examinations are known collectively as assessment audits (kazei shobun no tame no chosa) and are described in the individual substantive tax laws, such as Article 234 of the Income Tax Law, 1 Article 154 of the Corporation Tax Law, 2 Article 62 of the Consumption Tax Law3 and Article 60 of the Inheritance Tax Law. 4 Tax audits under existing law can be divided broadly into four categories.5 (1) Audits under Individual Tex Laws This category includes the abovementioned assessment audits (correction, determination, recorrection, administrative assessment, etc.) as well as audits to adjudicate administrative review cases such as claims for correction, objections and NTT review. (2) Delinquency Audits These audits have the aim of discovering the extent of assets held by a tax defaulter under Articles $142 \mathrm{ff}$. of the National Taxes Collection Law. 6 (3) Audits under the National Taxes Infringement Control Law7 (Criminal Tax Audits) Where it is considered that the taxpayer is engaging in tax evasion ("deception or other unfair conduct"), an audit may be conducted to ascertain the true factual matrix. (4) Purely Voluntary Audits These audits do not necessarily have a basis in legislation, but are a form of administrative guidance. 8 The various kinds of extra-legal inquiries (including correspondence inquiries) can also be seen as falling within this category. Types of Audit depending on whether the contents of the return are simple or complex, the Tax Office determines whether to conduct an interview (office) audit or a field audit. 
Interview audits are conducted at the Tax Office which has jurisdiction over the area where the taxpayer is resident. Field audits normally occur at the place where the taxpayer's books, records and original documents are kept. The taxpayer may alter the time and place of a field audit by contacting the Tax Office by telephone. (1) Interview Audit (Office Audit) Interview audits are conducted when the revisions required to the contents of the return are relatively simple. A notification is mailed to the taxpayer to summon him or her to the Tax Office. This notification will contain a proposed date and time for interview, which can be altered at the taxpayer's request. Where the contents of the return can be clarified over the phone or by the taxpayer mailing the relevant documents to the Tax Office, the Audit Officer may dispense with the requirement to attend the Tax Office personally. (2) Field Audit The date and time for a field audit is normally notified to the taxpayer or his or her zeirishi by telephone, and never in writing. There is no provision as to how much notice must be given, but current practice is to allow four to seven days before the audit. If the date and time proposed by the Tax Office is not convenient, the taxpayer may request an alteration. Audits may also occur without prior appointment. According to a survey of Tokyo Zeirishi Association members,17 6.0\% had experienced such surprise audits. These surprise audits were most common for industries engaged in cash transactions, and the methods employed are generally forceful[87].

\section{Tax examinations}

[Field examination of self-assessed income tax】

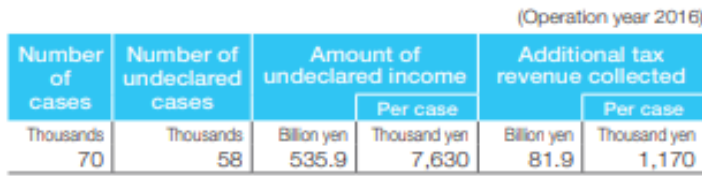

【Field examination of withholding income tax】

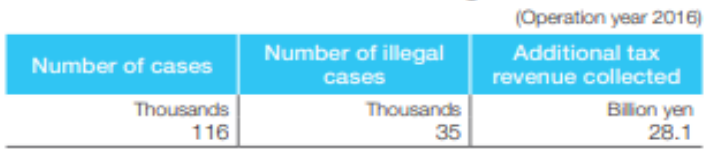

* The amount of additional tax revenue collected in comection with the hoome obtained on and after January 1, 2013 includes special income tax for reconstruction.

[Field examination of corporation tax】

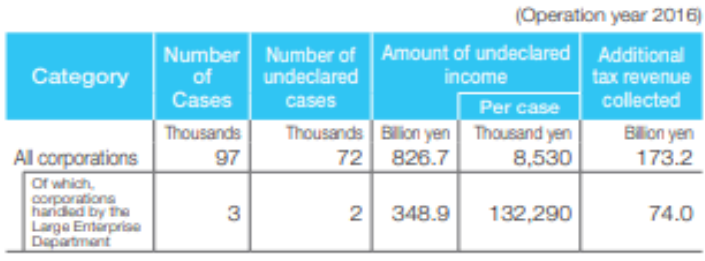

[Field examination of consumption tax】

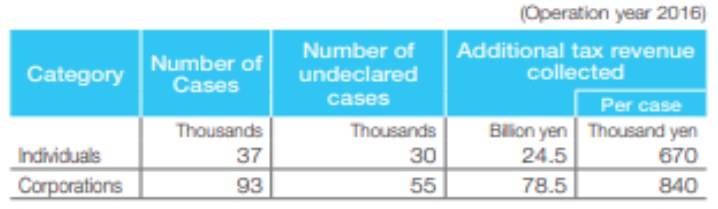

【Field examination of inheritance tax】

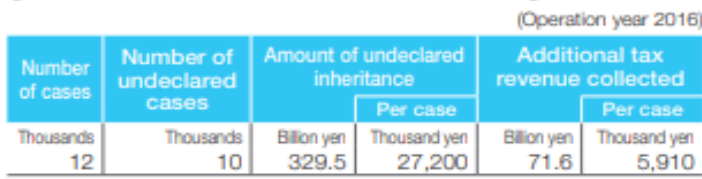

[Collected number of statutory information]

(Operation year 2016)

\begin{tabular}{l|r}
\multicolumn{1}{c|}{ Statutory information } & Number collected \\
\hline & Thousands \\
Withholding record of employment income & 21,932 \\
\hline Payment record of interest & 14,447 \\
\hline Payment record of dividends & 64,533 \\
\hline Other & 261,781 \\
\hline \multicolumn{1}{c|}{ Total } & 362,693 \\
\hline
\end{tabular}

Table National Tax Agency Report Japan.2018 [88] 


\section{CONCLUSION}

Having analyzed the experience and model of foreign countries, it is necessary to come up with the following characteristics in them. Specially, first, the tax authorities are formed in two models in terms of structure. The first will be available as an agency within the Ministry of Finance of the tax authorities (the United States and European countries), the second will be formed as a separate state body (Committee) independent of the financial authorities of the tax authorities (CIS countries, in particular Uzbekistan); secondly, in the tax administration there is a database on the choice of conducting tax inspections and condemning entrepreneurs ' compliance with tax legislation, this special program limits the human factor in the verification of taxpayers, as well as freeing those who comply with the laws from inspections; thirdly, there are two models of tax inspection, the first is the US model, in which the type of inspection appears 3 pcs, the correspondence audit-the exchange of taxpayer documents by mail at the request of the Tax Authority; the second is a meeting in the Office of the tax authority with the call of the taxpayer, third field audit-refers to complex verification of the taxpayer's accounting documents, mainly when he goes to the territory of the business entity. The second model is a European model, in which inspections are made in 2 views, there are two types of tax inspections: desk audit inspection in the tax authority and field tax audit - inspection in the territory of the taxpayer;fourth, the procedure for conducting tax inspections, in particular the procedure for the duration and notification of inspections (Germany) is classified according to the category of business entities (large, medium and small business entities);fifth, in order to protect the rights and interests of taxpayers in tax inspections, a separate legislative act on the rights of taxpayers is adopted, in which the rights and obligations of taxpayers in the inspection are established (before the beginning of the inspection, the rights and obligations in this document are explained or an extract from the document is provided);sixth, the institute for the protection of the rights of taxpayers as a complex process of tax inspections and filing complaints with the aim of ensuring the legality of the activities of the tax authorities exists in two forms: appeal to the administrative body or appeal to the Tax Court; seventh, the procedure for joint tax audits between states has also been introduced, since tax audits leave the national jurisdiction and occupy an international area. Proceeding from the above, in order to improve the system of tax inspections in the Republic of Uzbekistan, the following are proposed:- reform of the concept of tax inspections, in particular in it should introduce a system of mutually beneficial cooperation between tax authorities and taxpayers;introduction of electronic information and document exchange system in order to increase the efficiency of business activities in tax authorities, as well as creation of a single electronic base for assessing employees and taxpayers of tax authorities;-in order to ensure the transparency and openness of the activities of the tax authorities, the financial expenses of the tax authorities, as well as information on the tax revenues, as well as statistical information on tax inspections and events conducted by the tax authorities;-to hear the report of the tax authorities in the parliament in order to ensure accountability of the tax authorities and to open the annual reports on the website;-in order to increase the efficiency of tax inspections, it is necessary to take preventive measures, 
provide the services of a tax consultant, explain to the taxpayer the favorable tax regime, and then tax audit should be last tool;refusal of time and excessive document turnover by the introduction of the electronic tax inspection print-card, as well as the introduction of privileges on checks on subjects using the electronic system;-it is desirable to move from the system of a separate tax authority to the system of financial authorities by optimizing the number of employees, in particular, optimizing the system of tax authorities.

\section{REFERENCES}

1. Explanatory Dictionary of the Uzbek language. A.Under the editorship of Madvaliev. Tashkent. 2006-2008" National Encyclopedia of Uzbekistan " State Scientific Publishing House.Tashkent. - P.56

2. S. I. Ozhegov, N. Yu. Shvedova. Explanatory dictionary of the Russian language 4th ed., add. - M.: A TEMP, 2006. - P.544

3. https://www.merriamwebster.com/dictionary/audit

4. Legal Encyclopedia of Uzbekistan. Tashkent. Justice.-2009-B.448

5. Tax theory: tutorial / mual.: A. Juraev, O. Meyliev, G'. Safarov. - T.: Tashkent Financial Institute, 2004.-P.27

6. Adam Smith, The Wealth of Nations: A Translation into Modern English, ISR/Google Books, 2015. Book 5 (Government Finances: Public Expenditure, Taxation and Borrowing), pages 423, 429. Ebook ISBN 9780906321706

7. Klepper, S., Nagin, D., 1989. The Anatomy of Tax Evasion. Journal of Law, Economics, and Organization, Vol. 5, No. 1, pp. 1-24.
8. Z. P. Gasieva, V. A. Kaitmazov. Improving the efficiency of tax audits. Article. Economics. Bulletin of the Moscow University of the Ministry of internal Affairs of Russia. No. 2/ 2019. - P. 239

9. S. A. Shornikov. Theoretical and legal basis for tax audits in the Russian Federation. Autoabstract. Diss. Phd. in law. M-2008, -P. 15

10. G.S. Aytkhojina. Genesis of tax audits. Article. Tax policy at the current stage. Bulletin of Omsk University. Economy Series. 2012. No. 1, -P.199

11. G.G. Nesterov, N.A. Paponov, A.V. Terzidi. Tax control: textbook-M.: Eksmo, 2009. C. 384

12. O. A. Mironova.Tax administration: textbook. - Moscow: omega -L Publishing house, 2005. - P.408.

13. N. N. Shestakova.Tax audits in the tax control system. Article. Economy.Socioeconomic and humanitarian journal of Krasnoyarsk state UNIVERSITY. 2018 N.1, P.18

14. T.A. Silvestrova, Yu.A. Sokolova, D.G. Nazarov. Tax control and assessment of its effectiveness. Article. Economics. Bulletin of the Russian University of cooperation.2018. N.1(31) - P.61

15. Y. A. Puzyrova. Tax audits in the tax control system (legal and organizational aspects) abstract. Diss. Cand. M-2009, - P. 8-9

16. M. N. Sadchikov. Desk and field tax audits as a form of tax control. Autoabstract. Candidate of legal Sciences-Saratov, 2010, P. 16

17. Yu. A. Krokhina. Tax law. Textbook. Moscow: "Юрайт publishing House", 2011-P. 191

18. A. V. Demin. Russian tax law. Textbook. M.: "Yurlitinform", 2006-P. 127

19. A.Tagaev, F.Khoshimov, G'. Roziev, K.Khotamov. Tax control. Training 
manual.- T.: "New century generation", 2010, - B.7

20. Y. Zikeev. Concept, types and procedure of tax audits. https://www.zakon.kz/4649050-ponjatietipy-i-porjadokprovedenija.html.26.08.2014

21. L. I. Kofler, Yu. P. Kashirina. Tax audits: types, procedure for conducting and registration of results. Article. Journal. Voronej Institute of Economics and law. "Territory of science".2017. No. 1. -P. 164

22. T. Y. Kurbatov. Legal forms and methods of tax control. Diss. Cand. of law. Moscow-2015, P-64

23. L. V. Spirina. Tax audits: textbookpractical guide. Moscow, 2007. - P. 6-7

24. V. A. Timoshenko, L. V. Spirina. Tax audits: textbook-practical guide. M., " Dashkov", 2009. - P. 15

25. M.A. Dudkin. Tax audits as one of the main forms of tax control // Russian law at the present stage: materials of scientific and practical conference of students and young scientists: on the 10th anniversary of the faculty of law of RSEU " RINH "(April 28, 2006)

26. Kupriyanova N. A. Leichenkova N. N. Tax law: textbook. Saratov state social and economic University. - Saratov, 2010. - P. 88

27. Vitaly Lipsky. Tax control during tax audits. Legea si viata(Ukraine).Aprilie 2017. -P.75

28. M.I.Alimardonov.Forms of tax control in the conditions of reform of the tax system and ways of its improvement. Scientific electronic journal "Economics and innovation technologies". № 3, March, 2012 year

29. K.Sindarov, I.Jumanazarov. Legal basis for verification of business entities. (Legislative and judicial practice) brochure. Tashkent "new generation of the century", 2006.-P44-45

30. I.A.Ergashev.Improvement of organizational and legal framework of tax administration. Dissertation. Doctor of philosophy in legal Sciences. Tashkent, 2019, -P.8

31. Isayeva F.B. Tax law. Textbook for students of bachelor degree 5240100jurisprudence. - Tashkent: TDYU, 2017. P.73

32. Katharina Gangl, Eva Hofmann, Erich Kirchler. Tax authorities' interaction with taxpayers: A conception of compliance in social dilemmas by power and trust. University of Vienna, Faculty of Psychology, Austria/ New Ideas in $\begin{array}{llll}\text { Psychology } & 37 \quad \text { (2015) } 13 \mathrm{e} 3 .\end{array}$ www.sciencedirect.com

33. Agumas Alamirew Mebratu. Impact of tax audit on improving taxpayers compliance: emperical evidence from Ethiopian revenue authority at federal level. International Journal of Accounting Research (IJAR) Vol. 2, No. 12, 2016. Ethiopia

34. Jean Bosco Harelimana. Effect of Tax Audit on Revenue Collection in Rwanda. Global Journal of Management and Business Research: D Accounting and Auditing Volume 18 Issue 2 Version 1.0 Year 2018 Type: Double Blind Peer Reviewed International Research Journal Publisher: Global Journals Online ISSN: 2249-4588 \& Print ISSN: 0975-5853

35. David John Hoey. Tax audit rules and firm behaviour. Thesis. Doctor of Philosophy. The University of Adelaide. 2015 P-19

36. Catherine $C$ Rotich, Symon K Kiprop, Paul $M$ Nzioki. The effect of audit case selection on tax audit effectiveness in south rift valley region, Kenya. International Journal of Academic Research and Development.ISSN: 2455- 
4197; Impact Factor: RJIF 5.22 Received: 14-09-2019; Accepted: 18-10-2019 www.academicjournal.in.Volume 4; Issue 6; November 2019; Page No. 69-75

37. Zakir Akhand and Michael Hubbard. Coercion, Persuasion, and Tax Compliance: The Case of Large Corporate Taxpayers. UK researchers. canadian tax journal / revue fiscale canadienne (2016) $64: 1,31-63$

38. Agung Darono(Indonesian Ministry of Finance), Danny Ardianto (PhD Candidate and Teaching Associate, Centre for Organisational and Social Informatics, Monash University) The use of CAATTs in tax audits-lessons from some international practices. Article. eJournal of Tax Research (2016) vol 14, no. 2, pp. 506-526

39. Suhirman Madjid.(Doctoral Candidate of Padjadjaran University - Bandung Indonesia) The Effect Tax Audit Quality and Service Quality On Tax Reporting Compliance (The cases of tax audit of Indonesian). Research Journal of Finance and Accounting www.iiste.org ISSN 22221697 (Paper) ISSN 2222-2847 (Online) Vol.6, No.12, 2015

40. Mohd Rizal Palil. Tax Knowledge and tax compliance determinants in Self Assessment System in Malaysia. A thesis submitted to The University of Birmingham for the degree of Doctor of philosophy. -P-47

41. Charles Vellutini. Key Principles of RiskBased Audits. Chapter 1. Risk-based tax audits : approaches and country experiences / Munawer Sultan Khwaja, Rajul Awasthi, and Jan Loeprick, editors. (c) 2011 The International Bank for Reconstruction and Development / The World Bank.Volume.P-15

42. Sacit Hadi Akdede. Corruption and tax evasion. Adnan Menderes University.
Doğuș Üniversitesi Dergisi, 7 (2) 2006, 141149ю Turkey.

43. Barış Yıldız.(Assistant Professor, Gümüşhane University) A Theoretical Analysis on Tax Auditing - Tax Compliance Determinants and Bomb Crater Effect. Article 2019. Turkey. -P.87

44. Frans Vanistendael. Legal Framework for Taxation. Tax Law Design and Drafting (volume 1; International Monetary Fund: 1996; Victor Thuronyi, ed.) -p.7

45. Joel Slemrod. (Professor of Economics, and Director of the Office of Tax Policy Research at the University of Michiga) Cheating Ourselves: The Economics of Tax Evasion. Journal of Economic Perspectives-Volume 21, Number 1Winter 2007-Pages 25-48

46. Antonio Pedone. (University of Rome "La Sapienza") Tax theory and tax practice: the problems of defining, measuring and assessing tax bases. Article. Saggi di Economia della Tassazione, Milano, Angeli, 2009, 17-38.

47. Sandro Casal. Experimental Essays on Social and Agency Dilemmas. A dissertation submitted to the Doctoral School in Economics and Management in partial fulfillment of the requirements for the Doctoral degree (Ph.D.) in Economics and Management. December 2014. Italy. University of Trento. -P.10

48. Unwilling or Unable to Cheat? Evidence from a Randomized Tax Audit Experiment in Denmark Henrik J. Kleven, Martin B. Knudsen, Claus T. Kreiner, Søren Pedersen, and Emmanuel Saez NBER Working Paper No. 15769. February 2010 JEL No. $\mathrm{H}_{3}$

49. Izlawanie Muhammad. Managing Mixed Responsibilities: A Grounded Theory of Malaysian Tax Auditors' Dispute Resolution Behaviour in Audit Settlement. A thesis in fulfilment of the 
requirements for the degree of Doctor of Philosophy. School of Taxation and Business Law. Australian School of Business . The University of New South Wales. March 2013 P.15

50. National database of legislation data, 31.12.2019 y., №02/19/CK/4256; 11.03.2020 y., №03/20/607/0279

51. Decree of the Cabinet of Ministers of the Republic of Uzbekistan № 320 "on measures for further improvement of activities of the bodies of the state tax service" dated 17 April 2019.

52. National database of legislation data, 29.05.2020 y., №10/20/3236/0695

53. National database of legislation data, 18.06.2020 y., №10/20/3247/0803

54. National database of legislation data, 30.06.2020 y., №10/20/3251/1053

55. Leonid Kuznetsov. Legal characteristics of the US tax system. ArticleMatters of Russian and International Law. 2017, Vol. 7, Is. 9A

56. https://www.irs.gov/pub/irs-utl/tbor2.pdf

57. https://www.law.cornell.edu/uscode/text/ 26

58. https://www.irs.gov/businesses/smallbusinesses-self-employed/irs-audits

59. Tax administration Information on IRS' Taxpayer Compliance Measurement Program. Report to the Honorable Joseph K. Knollenberg, House of Representatives. United States General Accounting Office. October 1995. GAO/GGD-96-21.

https://www.gao.gov/assets/230/221808.p df

60. https://codes.findlaw.com/in/title-6taxation/

61. Internal Revenue Service Data Book, 2019. https://www.irs.gov/pub/irspdf/p55b.pdf

62. Comprehensive Taxpayer Attitude Survey (CTAS) 2019. Research, applied analytics
\& statistics (RAAS) statistics of income (SOI), statistical services branch. 3/11/2020Publication 5296 (Rev. 3-2020) Catalog Number 71353Y Department of the Treasury Internal Revenue Service www.irs.gov. https:// www. irs.gov /pub/irs-pdf/p5296.pdf

63. https://www.canada.ca/en/revenueagency/corporate/about-canada-revenueagency-cra/canada-revenue-agencystructure-operational-framework.html

64. Canada Revenue Agency Act. S.C. 1999, c. 17. Last amended on June 17, 2019. https://laws-lois.justice. gc.ca/PDF/C10.11.pdf

65. https://www.canada.ca/en/revenueagency/services/formspublications/publications/ic71-14/taxaudit.html

66. https://www.assembly.nl.ca/Legislation/sr /Regulations/rc110073.htm

67. I. I. Kucherov. Tax administration and anti-tax evasion in Canada.Article.The tax Bulletin. http:// www.nalvest.ru/nvarticles/detail.php?ID=26559

68. https://www.canada.ca/content/dam/craarc/formspubs/pub/rc4188/rc4188-18e.pdf

69. Moore Stephens. Doing Business in $\begin{array}{lll}\text { France } & 2018 . & -P .15\end{array}$ https://www.lexology.com /library/ detail.aspx? g=2fgcbgc6-9423-47df-8faa073d9925bcoo

70. https://coffra.de/wpcontent/uploads/2018/11/MooreStephens_Doing-BusinessFrance_2018.pdf

71. https://www.ciat.org/Biblioteca/Conferen ciasTecnicas/2013/Ingles/2013_topic3_me unier_Francia.pdf

72. https://taxsummaries.pwc.com/france/cor porate/tax-administration

73. https://www.lexology.com/library/detail.a spx?g=a3957c2c-64a6-4160-a4cafocac $990 e c a 8$ 
74. https://www.bzst.de/EN/Authorities/auth orities_node.html

75. Tax Audits in Germany: a Primer and a Plan Rosemarie A. Rhines, Scott $M$. Bennett and Silke Bacht The International Lawyer Vol. 37, No. 4 (WINTER 2003), pp. 997-1008 Published by: American Bar Association

https://www.jstor.org/stable/40707866

Page Count: 12

76. Butuzova, A. S. On the organization of tax control in Germany / A. S. Butuzova. Text: direct // Economics, management, Finance: proceedings of the VIII international conference. scientific Conf. (Krasnodar, February 2018).Krasnodar:Novation,2018.-P43-46. - URL: https:/moluch.ru /conf/econ/ archive/264/13689/ (дата обращения: 31.07.2020).

77. Moore Stephens. Doing Business in Germany 2018 https://www.mooreglobal.com/MediaLibsAndFiles /media/ MooreStephens/Documents/Doing\%2obu siness\%20guides/DBI-Germany-2018.pdf

78. Doing Business in South Korea 2018. https://dfk.com/uploads/assets/bba029534c9b-4fac-a947745f33 fb234a/DFK-DoingBusiness-in-South-Korea-2018.pdf

79. https://www.lexology.com/library/detail.a spx?g=f8a13eb6-6289-4b50-b8ed0191c4ba8c60

80. South Korea Tax Profile. KPMG Asia Pacific Tax Centre .March 2018 https://assets.kpmg/_ content/dam/ $\mathrm{kpmg} / \mathrm{xx} / \mathrm{pdf} / 2018 / 08 /$ south-korea2018.pdf

81. https://taxsummaries.pwc.com/republicof-korea/corporate/tax-administration

82. Korean Tax Update. Samil Commentary. February 2020. https://www.pwc.com/kr/ko/publications/ samil- commentary/samilcommentary_feb2020 en.pdf

83. Guidance On Tax Audit Procedure. National Tax Service Instructions No. 1661. 2007.7.27 https:// www.nts.go.kr/inc/download.asp?file_url =/eng/files/KoreanTaxation/80610.pdf\&fil e_nm=80610.pdf

84. https://www.eu-japan.eu/taxesaccounting/practical-guides/structure-taxadministration

85. National Tax Agency Report 2019. https://www.nta.go.jp/english/Report_pd f/2019e_04.pdf

86. https://www.lexology.com/library/detail.a spx?g=4b417336-e1a3-4f54-96b7f491foc5ba8e

87. Koji Ishimura. Professor of Law School Hakuoh University. The State of taxpayers rights in Japan. A Survey of the Legal Situation. Institute for International Trade Law, Asahi University Gifu, Japan 1995 -P.46-47, 49 http://pijweb.net/pdf/stj_eng/1.pdf

88. https://www.nta.go.jp/english/Report_pd f/2018e.pdf 